\title{
PENGARUH PEMBERIAN EDAMAME (Glycin max (L) merrill) TERHADAP PRODUKSI ASI PADA IBU NIFAS PRIMIPARA DI PRAKTIK BIDAN MANDIRI (PMB) DILLAH SOBIRIN KECAMATAN PAKIS KABUPATEN MALANG
}

\author{
Program Studi Kebidanan Politeknik Kesehatan RS dr. Soepraoen Kesdam V/Brawijaya Malang

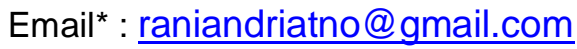 \\ HP : +6285731412999
}

\begin{abstract}
ABSTRAK
Pemberian Air Susu lbu (ASI) eksklusif merupakan investasi terbaik bagi kesehatan dan kecerdasan anak.Salah satu penyebab rendahnya pemberian ASI Eksklusif adalah asupan gizi yang rendah dan jumlah ASI yang diproduksi tidak cukup untuk memenuhi permintaan bayi.Kedelai sayur (Glycine max L.Merill), dikenal dengan sebutan Edamame memiliki potensi untuk nutrisi ibu menyusui, karena mengandung senyawa fitosterol yang berfungsi meningkatkan dan memperlancar produksi ASI (efek lactagogum).Tujuan penelitian ini untuk mengetahui pengaruh pemberian edamame (Glycine max L.Merill) terhadap produksi ASI pada ibu nifas primipara di Praktik Mandiri Bidan (PMB) Dillah Sobirin Kecamatan Pakis Kabupaten Malang.Metode penelitian menggunakan eksperimen dengan pendekatan one group pretest posttest.Sampel penelitian adalah ibu nifas primipara hari ke 3-7 sebanyak 20responden.Pengambilan sampling menggunakan purposive sampling.Pemberian edamame sebanyak 65 gram /hari selama 5 hari.Analisis secara bivariat menggunakan uji statistik wilcoxon. Hasil penelitian didapatkan $p$ value $=0,009$ dengan demikian Ho ditolak dan Ha diterima yang berarti ada pengaruh pemberian Edamame terhadap produksi ASI pada ibu nifas primipara hari ke 3-7 di PMB Dillah Sobirin Pakis Kabupaten Malang. Saran kepada petugas kesehatan diharapkan dapat memberikan asupan nutrisi yang tepat pada ibu nifas saat menyusui sehingga mampu menunjang keberhasilan program pemerintah dalam upaya peningkatan cakupan pemberian ASI Eksklusif.
\end{abstract}

Kata kunci: Edamame (Glycin max (L) merrill), produksi ASI, ibu nifas primipara

*Korespondensi: Rani Safitri. Surel: raniandriatno@gmail.com 


\section{PENDAHULUAN}

Kebutuhan nutrisi terbaik bagi bayi selama 6 bulan pertama adalah Air Susu Ibu (ASI).Di dalam ASI mengandung nutrisi alamiah untuk kebutuhan energi dan zat yang dibutuhkan selama 6 bulan pertama kehidupan bayi.Seorang ibu sering mengalami masalah dalam pemberian ASI eksklusif, salah satu kendala utamanya yakni produksi ASI yang tidak lancar. Hal ini akan menjadi faktor penyebab rendahnya cakupan pemberian ASI eksklusif kepada bayi baru lahir (Safitri, 2016). Air Susu lbu (ASI) mengandung lemak rantai panjang dan enzim lipase.Mineral dalam ASI kadarnya sangat sedikit tetapi dapat memenuhi kebutuhan bayi sampai 6 bulan.Lemak ASI adalah penghasil kalori (energi) utama dan merupakan komponen zat gizi yang sangat bervariasi.Lebih mudah dicerna karena sudah dalam bentuk emulsi. Bayi yang tidak mendapatkan ASI lebih banyak menderita penyakit jantung koroner di usia muda (Atika dan Eni, 2010).

Pemberian ASI dapat mengurangi angka kematian bayi. Hal tersebut sesuai dengan hasil penelitian di Ghana yang menunjukkan bahwa $22 \%$ kematian bayi baru lahir dapat dicegah dengan memberikan ASI pada satu jam pertama setelah kelahiran dan dilanjutkan pemberiannya sampai enam bulan (Nurliawati, 2010).

Berdasarkan hal ini maka upaya perbaikan gizi bayi 0-6 bulan dilakukan melalui perbaikan gizi ibu sebelum dan pada masa pemberian ASI eksklusif. Di Indonesia, persentase menyusui eksklusif semakin menurun dengan meningkatnya kelompok umur bayi. Pada bayi yang berumur 5 bulan menyusui eksklusif hanya $15,3 \%$ pada tahun 2010, tetapi telah meningkat sebesar 36,2 \% pada tahun 2013, sementara bayi menyusui eksklusif 6 bulan sebesar 30,2 \%.Target pemberian ASI eksklusif sebesar $80 \%$ pada tahun 2015 (Kementrian Kesehatan, 2015).
Ada beberapa penyebab rendahnya pemberian ASI eksklusif, salah satu diantaranya adalah ibu merasa ASI-nya tidak mencukupi kebutuhan bayi. Sekitar 35\% ibu menghentikan pemberian ASI secara eksklusif pada beberapa minggu post partum karena merasa ASI kurang dan bayi merasa tidak puas (WHO, 2002).

Kedelai sayur (Glycine max L.Merill, dikenal dengan sebutan Edamame di Jepang dan Mau Doudi China, merupakan salah satu jenis kacang-kacangan yang termasuk dalam kategori tanaman sayuran (green soybean vegetable). Tanaman ini merupakan salah satu sayuran penting di Jepang, Taiwan, China, dan Korea.Edamame termasuk tanaman tropis dan dijadikan sebagai sayuran serta makanan kesehatan. Sayuran ini kaya kandungan protein, kalsium, zat besi, vitamin A, B1, dan C. Selain kandungan gizi tersebut, disebutkan pula kedelai sayur kaya kandungan kalium, asam askorbik, serta vitamin $\mathrm{E}$ dengan persentase kandungan nutrisi $40 \%$ protein, $20 \%$ lemak (tanpa kolesterol), 33\% karbohidrat, 6\% serat, dan 5\% abu (pada berat kering). Tanaman edamame merupakan bahan makanan lokal yang memiliki potensi untuk nutrisi ibu menyusui, karena mengandung senyawa fitosterol yang berfungsi meningkatkan dan memperlancar produksi ASI (efek lactagogum).Secara teoritis, senyawasenyawa yang mempunyai efek lactagogum diantaranya adalah sterol.Sterol merupakan senyawa golongan steroid (Sciarappa, 2004).Selain itu, kandungan vitamin A yang tinggi dalam edamame $95 \mathrm{SI}$ dapat meningkatkan produksi ASI.Vitamin A perlu diberikan dan penting bagi ibu selama dalam masa nifas.Vitamin A bagi ibu nifas dapat menaikkan volume ASI (Cahyanto, 2013).Kedelai diketahui mengandung isoflavon khususnya genistein dan daidzein yang diketahui berperan dalam menginduksi hormon prolaktin 
sehingga meningkatkan produksi ASI (Pramitasari, et al, 2017).

\section{METODE PENELITIAN}

Jenis penelitian ini adalah eksperimen dengan desain one group pretest posttest.Penelitian dilaksanakan di PMB Dillah Sobirin Kecamatan Pakis Kabupaten Malang tahun 2018. Sampel penelitian adalah ibu nifas primipara hari ke 3-7 yang menyusui, produksi ASI kurang, puting susu menonjol dan tidak mengkonsumsi obat pelancar ASI sebanyak 20 responden. Pengambilan sampel menggunakan teknik purposive sampling berdasarkan kriteria inklusi oleh petugas lapangan atau peneliti. Ibu yang bersedia ikut dalam penelitian ini menandatangani informed consent yang dibuat oleh peneliti. Pemberian edamame dengan cara direbus dan konsumsi pagi hari pukul 07.00 sebanyak 65 gram/hari selama 5 hari. Data yang dikumpulkan adalah karakteristik sampel pada awal penelitian menggunakan kuesioner, produksi ASI dilihat dengan indikator jumlah Buang Air Besar/ Buang Air Kecil Bayi, Kualitas tidur bayi dan peningkatan berat badan bayi menggunakan lembar observasi. Analisis secara bivariat menggunakan uji statistik wilcoxson dengan batas kemaknaan $\alpha$ 0,05.

\section{HASIL PENELITIAN \\ Data Umum Penelitian}

Karakteristik Ibu Nifas Primipara di BPM Dillah Sobirin Pakis Kabupaten Malang Berdasarkan Umur

\begin{tabular}{lcc}
\hline \multicolumn{1}{c}{ Variabel } & Frekuensi & $(\%)$ \\
\hline Umur & & \\
$<20$ Tahun & 2 & 10 \\
20-25 Tahun & 13 & 65 \\
26-35 Tahun & 5 & 25 \\
>35 Tahun & 0 & 0 \\
Pendidikan & & \\
SD & 0 & 0 \\
SMP & 7 & 35 \\
SMA & 10 & 50 \\
Perguruan Tinggi & 3 & 15
\end{tabular}

\begin{tabular}{lcc}
$\begin{array}{l}\text { Pekerjaan } \\
\text { IRT }\end{array}$ & 12 & 60 \\
SWASTA & 8 & 40 \\
$\begin{array}{l}\text { Keadaan } \\
\text { Payudara }\end{array}$ & & \\
$\begin{array}{l}\text { Tegang } \\
\text { Sedikit Tegang }\end{array}$ & 14 & 70 \\
Tidak tegang & 6 & 30 \\
Frekuensi BAK & 0 & 0 \\
bayi & & \\
1-3 kali sehari & 0 & 0 \\
4-6 kali sehari & 7 & 35 \\
6-8 kali sehari & 13 & 65 \\
$\begin{array}{l}\text { Frekuensi BAB } \\
\text { bayi }\end{array}$ & & \\
1-2 kali sehari & 4 & 20 \\
3-4 kali sehari & 16 & 80 \\
Paritas & & \\
Primipara & 20 & 100 \\
Multipara & 0 & 0 \\
\hline
\end{tabular}

Berdasarkan tabel di atas dapat diketahui bahwa usia dari 20 responden sebagian kecil $(10 \%)$ berusia $<20$ tahun dan sebagian besar (65\%) berusia 20 25 tahun. Variasi pendidikan yang telah dienyam oleh ibu setengahnya (50\%) responden berpendidikan SMA dan sebagian kecil (15\%) responden berpendidikan Perguruan Tinggi.Sebagian besar (60\%) tidak bekerja/IRT, dan hampir setengahnya $(40 \%)$ bekerja swasta.Sebagian besar (70\%) keadaan payudara tegang saat belum menyusui bayinya dan hampir setengahnya $(30 \%)$ keadaan payudara sedikit tegang sebelum menyusui.Hampir setengahnya (35\%) frekuensi BAK 4-6 kali sehari dan sebagian besar (65\%) frekuensi BAK 68 kali sehari.Sebagian kecil (20\%) frekuensi BAB 1-2 kali dan hampir seluruhnya (80\%) frekuensi $B A B$ 3-4 kali sehari.Serta 20 responden seluruhnya (100\%) primipara.

\section{Data Khusus Penelitian}

Produksi ASI sebelum diberikan Edamame (Glycin max (L) merril)di BPM Dillah Sobirin Pakis Kabupaten Malang. 


\begin{tabular}{|c|c|c|}
\hline Karakteristik & Frekuensi & $\%$ \\
\hline Kurang & 17 & $85 \%$ \\
\hline Sedang & 3 & $15 \%$ \\
\hline Baik & 0 & $0 \%$ \\
\hline Jumlah & $\mathbf{8}$ & $\mathbf{1 0 0} \%$ \\
\hline
\end{tabular}

Berdasarkan tabel di atas dapat diketahui bahwa dari 20 responden hampir seluruhnya (85\%) mengalamiproduksi ASI yang kurang dan sebagian kecil (15\%) mengalami produksi ASI sedang.

Produksi ASI setelah diberikan Edamame (Glycin max (L) merrill) di BPM Dillah Sobirin Pakis Kabupaten Malang.

\begin{tabular}{|c|c|c|}
\hline Karakteristik & Frekuensi & $\%$ \\
\hline Kurang & 0 & $0 \%$ \\
\hline Sedang & 7 & $35 \%$ \\
\hline Baik & 13 & $65 \%$ \\
\hline Jumlah & $\mathbf{2 0}$ & $\mathbf{1 0 0} \%$ \\
\hline
\end{tabular}

Berdasarkantabel di atas dapat diketahui bahwa dari 20 responden sebagian besar (65\%) mengalami produksi ASI baik dan hamper setengahnya (35\%) mengalami produksi ASI sedang.

\section{Pengaruh Pemberian Edamame (Glycin max (L) merrill) Terhadap Produksi ASI Pada Ibu Nifas Primipara Hari Ke 3-7 di BPM Dillah Sobirin Pakis}

Berdasarkan hasil analisa data dapat diketahui bahwa hasil uji analisa data menggunakan Wilcoxson menunjukkan hasil 0,009 dimana $\alpha$ $(0,05)$ yang berarti $p$ value kurang dari nilai a yang menunjukan Ho di tolak dan $\mathrm{H} 1$ diterima yakni ada pengaruh pemberian Edamame (Glycin Max (L) Merrill) terhadap produksi ASI pada ibu nifas primipara hari ke 3-7 di BPM Dillah Sobirin Pakis Kabupaten Malang.

\section{PEMBAHASAN}

Status gizi ibu menyusui memegang peranan penting untuk keberhasilan menyusui.lbu yang sedang menyusui harus makan lebih banyak daripada biasanya dan lebih bergizi, kalori sebesar $550 \mathrm{kal} / \mathrm{hari}$ dan protein 17 gram per hari dengan jumlah vitamin $A$, thiamin dan riboflavin cukup tinggi. Untuk itu perlu makanan seimbang dengan prinsip yang sama dengan makanan ibu hamil, tetapi jumlahnya lebih banyak dan gizi lebih baik. Jika produksi ASI kurang baik, makanan yang dianjurkan untuk dikonsumsi ibu seperti daun berwarna hijau (Handayani, 2011).Berdasarkan survei yang telah dilakukan Radharisnawati, et al. (2017), dari hasil wawancara dengan 11 orang responden 4 diantaranya mengatakan ASInya tidak lancar dikarenakan tidak suka mengkonsumsi sayuran hijau. Sedangkan 7 diantaranya mengatakan ASInya lancar dikarenakan mereka mengkonsumsi susu, sayuran hijau, dan kacang-kacangan.

Wanita yang mengonsumsi protein kedelai ketika menyusui tidak hanya meningkatkan asupan protein untuk tubuhnya, tapi juga mendapat manfaat kesehatan yang ada pada kedelai.lbu menyusui membutuhkan sekitar 71 gram protein setiap hari.Ini tidak hanya jumlah protein yang dibutuhkan agar tubuh sendiri berfungsi normal, tapi juga yang dibutuhkan untuk laktasi.Selain itu, bayi yang menyusu ASI membutuhkan protein dari ASI untuk perkembangannya.Meski mendapat protein dalam jumlah yang dibutuhkan tidak terlalu sulit, beberapa wanita yang terbatas pola makannya membutuhkan bantuan untuk mendapat jumlah ini, termasuk vegetarian dan wanita yang tidak bisa mengonsumsi makanan tinggi protein (Ata, 2017).

Kedelai sayur atau edamame (Glycine max L.Meril) mempunyai potensi dalam menstimulasi hormon oksitoksin dan prolaktin.Kandungan alkaloid, polifenol, steroid, flavonoid dan substansi lainnya yang efektif dalam meningkatkan dan memperlancar produksi ASI.Isoflavon yang terkandung pada edamame merupakan asam amino yang memiliki 
vitamin dan gizi dalam kacang kedelai yang membentuk flavonoid.Flavonoid merupakan pigmen, seperti zat hijau daun yang biasanya berbau. Zat hijau daun memiliki banyak manfaat bagi kesehatan tubuh.Secara garis besar, manfaat dari isoflavon yang terkandung pada edamame adalah meningkatkan metabolisme dalam tubuh.Isoflavon merupakan nutrisi yang dibutuhkan oleh tubuh, mencegah sembelit, meningkatkan sistem kekebalan tubuh, menguatkan tulang dan gigi, mengendalikan tekanan darah, mengendalikan kadar kolesterol, mencegah resiko obesitas dan menghilangkan gejala penyakit maag. Isoflavonmerupakan asam amino yang memiliki vitamin dan gizi yang membentuk flavonoid. Isoflavon sendiri memiliki manfaat meningkatkan metabolism dalam tubuh, mencegah sembelit, meningkatkan system kekebalan tubuh, menguatkan tulang dan gigi. Isoflavon atau hormone phytoestrogen merupakan hormone estrogen yang diproduksi secara alami oleh tubuh dan bisa membantu kelenjar susu ibu menyusui agar memproduksi ASI lebih banyak (Selin, et al, 2010).

Refleks prolaktin secara hormonal untuk memproduksi ASI,waktu bayi mengisap puting payudara ibu terjadi rangsangan neurohormonal pada putting susu dan areola ibu. Rangsangan ini diteruskanke hipofisis melalui nervus vagus, kemudian kelobus anterior. Dari lobus ini akan keluar hormon prolaktin, masuk ke peredaran darah dan sampai pada kelenjar-kelenjar pembuat ASI. Kelenjar ini akan terangsang untuk menghasilkan ASI (Murtiana, 2011). Oksitosin merupakan merupakan hormon yang berperan untuk mendorong sekresi air susu (milk let down). Peran oksitosin pada kelenjar susu adalah mendorong kontraksi selsel mioepitel yang mengelilingi alveolus dari kelenjar susu, sehingga dengan berkontraksinya sel-sel mioepitel isi dari alveolus akan terdorong keluar menuju saluran susu, sehingga alveolus menjadi kosong dan memacu untuk sintesis air susu berikutnya (Djama, 2018).

Korelasi ini sesuai dengan hasil penelitian yang dilakukan oleh penelitian Agil (1987) dalam Murtiana (2011), menyatakan bahwa tanaman yang berkasiat pada peningkatan sekresi air susu (laktogogum) mempunyai kemungkinan: mengandung bahan aktif yang bekerja seperti Prolactin Releasing Hormon (PRH), (2) mengandung bahan senyawa steroid,(3) mengandung bahan aktif yang berkhasiat seperti prolaktin dan (4) mengandung bahan aktif yang berkhasiat seperti oksitosin (Djama, 2018).

Penelitian Selin, et. al (2010) menyatakan bahwa isoflavon dengan kadar yang lebih tinggi pada bayi ditemukan pada ibu yang rutin mengkonsumsi kedelai. Isoflavon dalam kedelai dipercaya dapat meningkatkan produksi ASI dan mengurangi risiko kanker payudara, meningkatkan pembelahan sel-sel payudara, menekan pertumbuhan selsel tumor, dan mekanisme yang lainnya.Didukung oleh penelitian Andrian, et al (2006) menyatakan bahwa ibu yang mengkonsumsi bahan makanan yang terbuat dari kedelai baik berupa susu kedelai dan olahan kedelai lainnya diyakini dapat meningkatkan kadar isoflavon dalam jaringan di payudara.Kedelai jika dikonsumsi secara rutin bisa berefek baik untuk kesehatan yaitu mencegah terjadinya kanker payudara.

Penelitian ini mengungkapkan
bahwa pemanfaatan edamame
(Glycine max L.Merill) dapat
meningkatkan produksi ASI, sehingga
diharapkan mampu menunjang
keberhasilan program pemerintah
dalam upaya peningkatan cakupan
pemberian ASI Eksklusif.

\section{SIMPULAN}

1. Berdasarkan hasil penelitian tabel distribusi produksi ASI ibu 
nifas primipara sebelum diberikan Edamame (Glycin Max (L) Merrill). Dapat diketahui bahwa dari 20 responden sebesar $85 \%$ mengalamiproduksi ASI yang kurang dan $15 \%$ mengalami produksi ASI sedang.

2. Berdasarkan hasil penelitian tabel distribusi produksi ASI ibu nifas primipara setelah diberikan Edamame (Glycin Max (L) Merrill). Hasil yang didapat dari 20 responden sebesar $65 \%$ mengalami produksi ASI baik dan 35\% mengalami produksi ASI sedang.

3. Ada pengaruh pemberian Edamame terhadap produksi ASI ibu nifas primipra hari ke 3-7 di BPM Dillah Sobirin Pakis Kabupaten Malang.

\section{DAFTAR PUSTAKA}

1. Andrian A Franke, Brunhild $M$ Halm, Laurie J Custer, Yvonne Tatsumura, and Sandra Hebshi. 2006. Isoflavones in breastfed infants after mothers consume soy. The American Journal of Clinical Nutrition, 84 ; 406-413. http://ajcn.nutrition.or

2. Ata. 2017. Efek Kedelai Untuk Ibu Hamil, Ibu Menyusui, dan Bayi.

https://www.ibupedia.com/artikel /kehamilan/efek-kedelai-untukibu-hamil-ibu-menyusui-dan-

bayi. diakses tanggal 27 November 2018.

3. Atika, Eni. 2010. Kapita Selekta ASI dan Menyusui. Yogyakarta: Nuha Medika

4. Cahyanto, Bibi Ahmad. 2013. Asupan Vitamin A, Perawatan Kesehatan, Produksi Air Susu Ibu (ASI), Dan Status Kesehatan lbu Nifas.Departemen Gizi Masyarakat. Fakultas Ekologi Manusia. Institut Pertanian Bogor.

5. Djama. 2018. Pengaruh Konsumsi Daun Kacang Panjang Terhadap Peningkatan
Produksi ASI pada Ibu Menyusui. Jurnal Riset Kesehatan. Vol 14 (1). Page 510

6. Handayani. 2011. Faktor-Faktor yang Berhubungan dengan Perilaku Pemberi ASI Eksklusif pada lbu Bayi 6-12 bulan di Wilayah Kerja Puskesmas Kecamatan Palmatak Kabupaten Kepulauan Anambas Provinsi Kepulauan Riau tahun 2011. Skripsi. Depok: UI

7. Kemenkes. 2015. Profil Kesehatan Indonesia 2014. Jakarta : Kemenkes RI

8. Murtiana, T, 2011. Pengaruh Konsumsi Daun Katuk dengan Peningkatan Produksi ASI pada Ibu Menyusui di Wilayah Puskesmas Sawah Lebar Kota Bengkulu Tahun 2011.Jurusan Kebidanan, Politeknik Kesehatan Bengkulu, Bengkulu.

9. Nurliawati, Enok. 2010. Tesis : Faktor-Faktor yang Berhubungan dengan Produksi ASI pada lbu Pasca Sectio Sesarea di wilayah Kota dan Kabupaten Tasikmalaya. http://lib.ui.ac.id. September 28, 2016

10. Pramitasari, et al. 2017. Pengembangan Minuman Kedelai Hitam untuk lbu Menyusui. Jurnal Ilmu Pangan dan Hasil Pertanian. Vol 1(1): page 1-10

11. Radharisnawati, N.K, Rina Kundre, Linnie Pondaag. 2017. Hubungan Pemenuhan Kebutuhan Gizi Ibu Dengankelancaran Air Susu lbu (Asi) Pada lbu Menyusuidi Puskesmas Bahu Kota Manado.e-journal Keperawatan (e-Kp). Volume 5 Nomor 1.

12. Safitri, Indah. 2016. Faktor Faktor Yang Mempengaruhi Kelancaran Produksi Asi Pada Ibu Menyusui Di Desa Bendan, Kecamatan Banyudono, Kabupaten Boyolali. Publikasi 
IImiah. Universitas Muhammadiyah Surakarta.

13. Sciarappa, W.J.,2004. Edamame:The Vegetable Soybean, Rutgers Cooperative Research and Extension, New Jersey

14. Selin Bolca, Mireia Urpi-Sarda, Phillip Blondeel, Nathalie Roche, Lynn Vanhaecke, Sam Possemiers, Nawaf Al-Maharik, Nigel Botting, Denis De Keukeleire, Marc Bracke, Arne Heyerick, Claudine Manach, and Herman Depypere. 2010. Disposition of soy isoflavones in normal human breast tissue. The American Journal of Clinical Nutrition, 94 ; 976-984. http://ajcn.nutrition.org.

15. Worls Health Organization. 2002. Report of the expert consultation on the optimal duration of exclusive breastfeeding. Geneva : World Health Organization 